\title{
Mefenamic Acid
}

National Cancer Institute

\section{Source}

National Cancer Institute. Mefenamic Acid. NCI Thesaurus. Code C47599.

An anthranilic acid and non-steroidal anti-inflammatory drug (NSAID) with anti-

inflammatory, antipyretic and analgesic activities. Mefenamic acid inhibits the activity of the enzymes cyclo-oxygenase I and II, resulting in a decreased formation of precursors of prostaglandins and thromboxanes. The resulting decrease in prostaglandin synthesis, by prostaglandin synthase, is responsible for the therapeutic effects of mefenamic acid. Mefenamic acid also causes a decrease in the formation of thromboxane A2 synthesis, by thromboxane synthase, thereby inhibiting platelet aggregation. 